\title{
What, If Anything, Can Labor Do to Rejuvenate Itself and Improve Worker Well-being in an Era of Inequality and Crisis-driven Austerity?
}

\section{Citation}

Freeman, Richard B. 2013. "What, If Anything, Can Labor Do to Rejuvenate Itself and Improve Worker Well-Being in an Era of Inequality and Crisis-Driven Austerity?" Perspektiven Der Wirtschaftspolitik 14 (1-2) (February): 41-56.

\section{Published Version}

doi:10.1111/pers.12003

\section{Permanent link}

http://nrs.harvard.edu/urn-3:HUL.InstRepos:13047660

\section{Terms of Use}

This article was downloaded from Harvard University's DASH repository, and is made available under the terms and conditions applicable to Open Access Policy Articles, as set forth at http:// nrs.harvard.edu/urn-3:HUL.InstRepos:dash.current.terms-of-use\#OAP

\section{Share Your Story}

The Harvard community has made this article openly available.

Please share how this access benefits you. Submit a story.

\section{Accessibility}




\section{What, if Anything, Can Labor Do to Rejuvenate Itself and Restore Full Employment and Raise Living Standards in an Era of Inequality and Crisis-driven Austerity?}

\section{Richard B. Freeman}

The economic position of workers has weakened in much of the advanced world. Over the past 30-40 years the share of national income going to labor has fallen. Labor earnings have become more unequally distributed. The proportion of workers in trade unions has trended downward, accompanied in some countries with commensurate declines in collective bargaining coverage. Union influence on the direction of the economy has diminished even in countries where firms and unions negotiate wage and wage conditions for most employments and even when left-oriented parties are in government. Increases in government deficts and debt resulting from the Great Recession have induced many governments to introduce austerity policies that are likely to perpetuate high joblessness and inequality into the forseeable future. Finance's speculative excesses effed market capitalism in the Recession but much of the costs will fall on labor into the foreseeable future.

There is no easy answer to the title question. As the phrase "if anything" indicates, it is unclear whether labor can rejuvenate itself and restore full employment and raise living standards in the face of inequality and austerity. Differences in the labor relations systems of countries, levels of inequality, the importance of money in politics, and the state of economies post the Great Recession will undoubtedly produce different responses among countries.

In this paper I examine the situation in the US, where the ability of trade unions to represent labor's interest has declined more than in any other major economy. Collective bargaining in the US is co-terminus with union density. For over half a century union density has steadily declined in the US private sector. In $20126.6 \%$ of private sector workers were union members (US BLS, 2013, table 3) a percentage below the level in 1900 when total density, then based almost entirely on private sector workers, was $6.8 \%$ (Freeman, 1998, p 291). In the 2000s unions gained so few workers in National Labor Relations Board (NLRB) representation elections and outside the process to make the antiunionists' dream of an effectively union-free labor market a realistic possibility for the next decade or so. American labor law and custom makes it difficult to substitute other forms of workplace labor activity for collective bargaining. It forbids employer-initiated works councils. It contains no mechanisms for mandatory extension of collective contracts as in many EU countries. Employers associations do not regularly discuss labor issues with the central union federation.

Unionism and collective bargaining have followed a different path in the public sector. Despite the continuous erosion of private sector unionism, from the 1960s through the 1980 unionisation expanded in the public sector so that about $37 \%$ of employees were union members in the 2000s, including teachers, police, firefighters, university professors, graduate student teaching assistants, and so on. When recession-induced budget crises hit cities and states in the late 2000s, however, opponents of unions attacked public sector bargaining as a contributing factor to the deficits. In the US federal system, state law governs state and local government collective bargaining. Some states encourage bargaining of public sector workers and employers. Other states, largely in the South, make

1 See www.unionstats.com, Union Membership, Coverage, Density, and Employment Among Public Sector Workers, 1973-2011. 
it illegal for public sector employers to bargain with unions. Following the 2008 elections, Republicandominated legislatures in several states with laws that ncouraged collective bargaining passed bills to restrict bargaining, outlaw dues checkoffs/agency fees (which provide a funding stream to unions), and limit union political activities. Wisconsin, the first state to enact laws favorable to public sector bargaining, addedprovisions to weaken collective bargaining for all workers except police and fire to its budget bill. Ohio sought to eliminate public sector bargaining for all state and local employees.

Opponents of the Wisconsin legislation forced the state's governor into a recall election but failed to turn him out of office. Opponents of the Ohio legislation overturned it in a state referendum. (Freeman and Han, 2012). But in 2012 the Republican dominated legislature in historically pro-union Michigan passed a bill to weaken unions there. At this writing anti-union groups have bills pending in the legislatures of many other states. The union response has been to circle their wagons to defend their shrinking part of the labor market rather than to seek positive reforms in society.

The experience of the US is extreme but nonethless informative for other advanced countries where crisis-driven austerity and inequality weaken union ability to represent workers and to maintain welfare state safety nets. The sluggish efforts by US unions to find alternatives to collective bargaining as union density fell is a "canary in the mine" warning to labor elsewhere. New efforts by labor activists, social entrepreneurs, and some US unions to develop alternatives to collective bargaining, on the other hand, suggests ways in which labor can push back to restore full employment and rising living standards for all. For their part, groups that view unions unfavorably will find US experience appealing.

The paper is divided into three sections. Section one reviews the decline in labor as a countervailing force to the power of capital to determine outcomes in modern capitalism, with particular attention to the collapse of the firm-based collective bargaining model in the US. Section two highlights the potential value for labor-based initiatives to reform the finance-dominated model of capitalism that underlies the crisis. Section three examines the new ways that activists, social entrepreneurs, and some unions in the US have mobilized workers and the public to rejuvenate labor and press for improved labor conditions outside of collective bargaining. There is a brief conclusion.

\section{Erosion of big labor}

The weakening of labor in advanced countries shows up in diverse measure of worker wellbeing and of institutional structure. Income inequality has increased in nearly all countries, though at different rates and to different levels. Using the ... data, I find that Gini coefficients increased in - of OECD countries. OECD earnings data show. In terms of levels, inequality in the US far exceeds that of other advanced economies, but some countries with traditionally low levels of inequality have experienced sizeable increaes. For instance, in Germany inequality in labor earnings increased sufficiently in the 2000s to move it from below to above average among OECD countries. Labor's share of national income fell in all advanced countries, though again at different rates and to different levels.

Conventional thinking explains the trend toward greater inequality as the result of increased trade with low wage developing countries that has effectively added to the pool of unskilled workers in advanced countries and of technological change that shifts demand for labor toward more skilled workers. The evidence for globalization's effect the earnings inequality in advanced countries seems fairly strong and getting stronger (see Autor, ....). The surprise is not that inequality increased in advanced countries but that it increased also in many developing countries, where standard trade models predicted that inequality would fall. To deal with this anomaly, analysts have added wrinkles to factor price equalization models and sought new measures of worker skills in developing countries. 
The case for technology is more questionable because we lack " measures of innovation" and have little reason to expect technology to favor skilled workers as opposed to unskilled workers, much less white collar workers as opposed to blue collar workers. In the context of "North-South" models of trade in which earnings of low skilled workers in advanced countries depend on those countries having access to the newest technologies, the rapid growth of higher education, investment in R\&D, and technology transfer to developing countries has arguably eroded the comparative advantage/monopoly of advanced countries in those technologies.

Analyses that link changes in income or earnings inequality to trade and technology, while insightful, invariably fall short of a full explanation of the shift in income distribution in countries such as the US where inequality has risen to such high levels. Since the same trade and technology shocks affect most advanced countries, moreover, it is hard to explain country differences in levels or changes in inequality, by those universal factors. This opens the door to country-based explanations of the changes in inequality as well, including changes and differences in labor institutions and policies.

Measuring the strength of labor institutions by union density, density has fallen in nearly all advanced countries. In the non-EU OECD countries, between - and - density dropped by xx points in Japan, by - points in Canada, and by - points in Australia (where in the 1990s John Howard's Work Choice Bill sought to ) and by - points in New Zealand. In all of these

But in the US US precipitous but others also experienced. EU maintaned CB, though with lower density unions inevitably have less bargaining clout. In all countries, nature of labo-management conflict. Strikes are down. In US employers increased their use of lockouts to pressure unions into wage or benefit cuts ${ }^{2}$. Within the organized sector, economic conditions forced many unions into concession bargaining.

In Usattitudes toward unions fallen when unemployment is high. In the Great Recession fell greatly, producing a huge an increasing proportion reported that they viewed unions unfavorably. A majority said that unions mostly harmed non-members. ${ }^{3}$ The increased disapproval of unions occurred primarily among Republicans, who increasingly saw unions as having too much power just below the arch-villain federal government. By contrast, the proportion of Democrats who view unions as having too much power places unions at the bottom of their list. ${ }^{4}$ I have not examined attitudinal changes in other countries.

\section{The Crisis of Finance-dominated Capitalism}

If weakening of labor influence improved operation of system, as many opponents of Big Labor believed it would and as many believed it had done prior to ... Before the Recession, many ... US flexibility. OECD Jobs Study favored. Countries who stuck with institutions such as Germany were viewed as needing. They missed out Reagan or Thatcher in the 1980s. . I take the implosion of Wall Street and global financial system, the Great Recession and sluggish recovery, and continued crisis in many EU countries as well as the continued jobs crisis in the US as indicating the need for re-balancing economies from finance toward labor and non-financial businesses.

\footnotetext{
Steven Greenhouse (2012) and John Wojcik (2012).

http://www.gallup.com/poll/12751/labor-unions.aspx reports all of the gallup poll results

The difference in the proportion of Republicans and Democrats who viewed unions as having too much power was a huge 49 points. This contrasts to modest partisan differences for other entities save for the federal government (41 point difference), see Gallup Poll (Saad 2011).
} 
Prior to the Great Recession (GR), economists and policy-makers heralded the "US jobs machine" as the epitome of a successful flexible labor market. The empirical basis for this view was the huge increase in US employment in the 1980s and 1990s $\mathrm{s}^{\mathrm{i}}$, which raised the ratio of employment to the working age in the US substantially above ratios in other advanced countries. Because Americans worked more hours and took fewer and shorter vacations, the gap between the US and other advanced countries was even greater in the ratio of annual hours worked to the working age population. ${ }^{\text {ii }}$ The US also had a relatively low rate of unemployment with exceptionally short spells of joblessness.

America's job creating performance led most analysts to downplay the "skeletons in the closet" of high earnings inequality; stagnant poverty rates, falling collective representation of workers, and reduced pension and health insurance coverage and conclude that US reliance on market forces produced a better functioning labor market than the collective bargaining and government interventions that proliferated throughout Europe. Many policy analysts predicted that if European countries could solve their employment problems by reforming their labor markets along US lines, as the following quote from an International Monetary Fund analysis shows:

"labor reforms could produce output gains of about 5 percent and a fall in the unemployment rate of about 3 percentage points. ... those benefits could be doubled by simultaneous efforts to increase competition in the product market."iii

Academic analysts offered "observations and conjectures on the US employment miracle" (Krueger and Pischke 1997) and argued over whether market flexibility or aggregate demand drove the US's superior job-creating performance (Schmitt, 2002).

What a difference the Great Recession has made!

Large job losses followed by sluggish employment growth in the recovery have gainsaid the 1990s-early 2000s vision of an exemplary US labor market. If you were to Google "great American jobs machine" in January 2013 you would come up with links to: The Great American Jobs Machine Is Conking Out"; Who Broke America's Jobs Machine? "The Late American Jobs Machine" and "Is the Great American Jobs Machine Finally Broken? ${ }^{\text {iv }}$ The main session on labor at the January 2013 American Economic Association asked "What happened to the US employment miracle?"

By contrast, if you were to Google "German labor market great recession"in January 2013 you would come up with links to: "What explains the German labor market miracle?" "Another Economic miracle: the German Labor Market and the Great Recession", and The German Labour Market Miracle". v Germany - the 1990s sick economy of Europe with its works councils, apprenticeship system, and social partner bargaining - the new peak labor market in advanced capitalism?

But the heart of ... was not labor but finance. Beginning in 1980s, US and many other countries ran a giant experiment in capital markets. Less developed countries had financial crisis by the $-\mathrm{xxx}$ in yy years, according to IMF data. Trusting the efficient UK bought into notion that finance had. But financial innovations There were The

Financial economics teaches us that the job of finance is to spread the effects of risks among large numbers of people, so that no one bears intolerable levels of risk (Shiller, 2003, p. 1) ${ }^{5}$ and to direct capital to its most productive uses. In the deregulated capital market of the 2000s, finance did the opposite. It increased risk through leveraging, speculation, and caveat emptor rent-seeking. It did so with practices that were chicanery at best and crime at worst. Restoring finance to its role as a

5 Shiller goes on to say that: "finance ... has made stunning progress in the second half of the twentieth century, both in theory and in practice (p. 11) ... risk does not disappear but its effects virtually disappear as the risks to the individual business are blended into large international portfolios where they are diversified away to almost nothing among the ultimate bearers of the risk, the international investors (2003, p. 3). 
productive force in the economy will require new institutions and modes of compensation, as part of a general overhaul of the relation between finance and the real economy. Since labour and normal citizens bear so much of the cost of the failure of finance to do its job, it is incumbent upon those who represent labour (be they unions, ministries of labour and social protection, elected officials, or employers who care about their workers) to seek such reforms. The experiment with laissez-faire finance came to a sudden end in September 2008, when Lehman Brothers went bankrupt. The Wall Street Journal referred to the subsequent implosion of banking and finance as "The Weekend Wall Street Died" (Craig, 2008).

The lesson from the past two decades is that the bankers and their allies in politics and academe will not make the necessary reforms by themselves.

\section{Nonunion labor activism without collective bargaining}

With collective bargaining coverage shrinking in the US, activists inside and outside of unions have sought new ways to represent worker interests. The spread of low-cost Internet-based information and communication tools made it easier for non-collective bargaining groups to mobilize citizens, organize demonstrations and campaigns, and identify and appeal to workers than in earlier years.

Table 1 three types of non-CB labor institutions that formed or developed between the late 1990s and 2000s in the US. Some of the institutions have spread to other countries, while others are US-centric though they may have country-specific parallels with which I am not familiar.

The first set consists of organizations that target broad economic issues and society at large seeking to bring attention and potential relief from problems that may not. The most famous such group are the Occupy Wall Street, which burst n September 2011, Occupy Wall Street (http://occupywallst.org/) protesters sat down in Zuccotti Park near Wall Street to demonstrate against economic inequality ${ }^{6}$. The disparate group of largely college graduates camped out under banners that read "we are the 99\%" did more to bring the problem of inequality to US policy discourse than academics or unions had done in the preceding two to three decades. ${ }^{7}$ Occupy spawned protests in the US and worldwide. ${ }^{8}$ The US occupy groups ranged from Wall Street savvy experts who write technical critiques of financial regulations (www.occupythesec.org) to city-based groups focused on local issues (www.occupyoakland.org) to university-based groups which target campus issues - Goldman-Sachs recruiting at Harvard for instance (www.occupyboston.org). ${ }^{9}$ With its non-partisan orientation and stress on identifying problems rather than offering solutions, the occupy movement has shown that modern information and communication technology and social media allows a small group without much money or organization to come together and create a local and global ruckus about important social issues ${ }^{10}$ But Occupy's lack of organization and connection to political or business institutions limits its effectiveness in producing social change to resolve the problems it has brought to US and world attention.

6 "OWSs main issues are social and economic inequality, greed, corruption and the perceived undue influence of corporations on government." (Dilek 2013).

7 In September 1981 unions organized a mass Solidarity march on Washington to protest the emerging recession spurred by economic policies of the Federal Reserve and Reagan Administration's effort to curb inflation.

8 See Rogers (2011) for a link to the google spreadsheet showing 747 activities in Fall 2011 under the Occupy banner.

9 For an analysis of the Occupy movement at Harvard University, see Cook and Rouse (2012); for a more critical view see Troia (2012).

10 See http://occupywallst.org/about/ and Take the Square (2011). 
Petition sites: change.org. On-line petition sites provide a platform for citizens to start and sign petitions to pressure governments or other organizations to change policies. Www.change.org, a forprofit certified B Corporation ${ }^{11}$ is currently the world's leading petition site. In the 2010 s it has expanded from its US base to many other countries. ${ }^{12}$ The site enables a citizen to express his or her voice on an issue easily. You go to the web site and click the "start a petition" button. The script asks a set of questions: Who do you want to petition? What do you want them to do? Why is this important? Then you write your petition and submit it. The site alerts people who might be interested in your cause and they may alert their friends and ... pow! The petition may go viral. Www.change.org makes money by selling its email database to charitable and other organizations who want to connect with people having particular interests.

In the fall of 2011, two petitions begun by Molly Katchpole, a 22 year old college graduate working as a nanny, demonstrated the power of Internet petitioning. In October the Bank of America added monthly fees to low income customers for using their debit cards. ${ }^{13}$ Customer Katchpole placed a petition on www.change.org asking BOFA to rescind the policy. ${ }^{14}$ It read: ${ }^{15}$

Brian T. Moynihan, President and CEO, Bank of America

I'm writing to express my deep concern over Bank of America's decision to charge customers \$5 a month to use their debit cards when making purchases.

The American people bailed out Bank of America during a financial crisis the banks helped create. You paid zero dollars in federal income tax last year. And now your bank is profiting, raking in $\$ 2$ billion in profits last quarter alone. How can you justify squeezing another $\$ 60$ a year from your debit card customers? This is despicable.

American consumers can't afford these additional fees. We reject any claims by BofA that this latest fee is somehow necessary.

Please, do the right thing. Reverse your decision to charge customers $\$ 5$ each month for using their debit cards to make purchases.

Sincerely,

Three hundred thousand people, signed the petition, including President Barack Obama. US Senator Durbin of Illinois responded to the petition on Twitter. Congress decided to "look at legislation for out-of-control banking fees." ${ }^{16}$ Most important, the media gave the petition national exposure, and people responded. Some customers left the Bank of America. Others threatened to leave. Faced with furious customers, the Bank of America dropped its banking fee.

Two months later Verizon announced that customers paying telephone bills on-line had to pay a $\$ 2$ fee. Customer Katchpole wrote a petition protesting the Verizon fee. Within hours her petition gathered over 130,000 signatures. The Federal Communications Commission, which regulates

11 In 2010 US states beginning with Maryland instituted a charter for a benefit or B-corporation, that commits itself to do more than seek profit-maximization for shareholders.

12 The same technology has spawned many other sites, such as www.labourstart.org, a pioneer in gathering and publishing labor news from around the world that regularly asks users to sign petitions when union leaders or members are arrested or endangered. Facebook has pages that organize petitions as well.

13

The Federal Reserve had capped the amount banks can charge merchants for processing debit-card purchases, so

BOFA and other large Banks decided to make up the money by charging low income consumers.

14 Colgrass (2011).

15 http://www.change.org/petitions/tell-bank-of-america-no-5-debit-cardfees?utm_source=share_petition\&utm_medium=url_share\&utm_campaign=url_share_before_sign

16 Wikipedia Contributors 2013a 
telecommunications, announced that it would investigate. But there was no need for regulators. As Katchpole's petition gained signatures, Verizon withdrew the fee. ${ }^{17}$

The occupy demonstrations and petition drives come from grass roots individual behavior. Relying extensively on Internet and social media communication they create new markets for people to come together and press society on issues that matter to them. Creating a new market for grass roots individuals to express themselves has an intrinsic appeal to market-oriented economists regardless of their views of the specifics of the issue. Demonstrations and petitions succeed if the issues they target meet the market test of getting enough individuals involved to force decision-makers to rethink decisions.

The AFL-CIO created Working America (www.workingamerica.org/) (WA) as a non-collective bargaining "community affiliate" to connect the federation to nonunion workers, in large part to extend union political influence beyond its declining membership. ${ }^{18}$ WA canvasses people in their homes to join. In 2012 WA reported having about 3 million members viewed as politically important such as Ohio, Pennsylvania, Virginia btained 135,000 members on-line, giving WA members throughout the country.. While the organization offers members involvement in a social movement focused on "the priorities that matter most to working people ... (and that can) . . . make a difference for your community, for America and for your working family," its primary goal is to get members to be politically active and vote for union-endorsed candidates. Until the Supreme Court's Citizens United decision in 2010, unions could not use their resources to proselytize non-members in political campaigns. ${ }^{19}$ They needed an organization like WA to be able to target non-member voters. By allowing all organizations to use their funds for political purposes, Citizens United has eliminated this rationale for unions funding WA.

With local offices in many areas and large membership, Working America has the potential to be much more than a top-down Washington-run AFL-CIO affiliate seeking to influence the votes of citizens outside the union movement. WA could decentralize its structure, develop procedures for members to elect leaders in local chapters and encourage chapters to experiment with their own ways of engaging the public and targeting workplace issues.

Occupation/Industry/Community Based Groups - ) Groups that seek to help workers in particular occupations or industries deal with labor market problems and that represent them in pressing governments for improved or better enforced regulations in the occupation or industry

Worker centers are community-based organizations that support low-wage workers, mostly from immigrant communities, in a variety of ways outside of collective bargaining. ${ }^{20}$ The centers give legal assistance to workers facing wage arrears (delayed or unpaid wages); advocate and lobby for legislation to improve work conditions and for authorities to implement existing laws; and seek to educate workers and their communities about ways to campaign on workers' behalf. The number of worker centers increased rapidly from a handful in the 1990s to on the order of 150-200 by the mid to late 2000s. ${ }^{21}$ They coalesced into two major national networks, the National Day Laborer Organizing

$17 \quad$ Frellick (2012).

18 For a detailed description see Freeman and Rehavi (2009).

19 Wikipedia Contributors (2013b).

20 For the most detailed analysis, see Janice Fine (2006).

21 Marculewicz and Thomas (2012) 
Network (NDLON) that had 43 member organizations in 2012, and the Interfaith Worker Justice (IWJ), which listed 26 worker centers that reached 17,000 workers in 2012. ${ }^{22}$ Impressed by what worker centers have done, in 2006 the AFL-CIO entered partnership with NDLON to "work together for state and local enforcement of rights as well as the development of new protections in areas including wage and hour laws, health and safety regulations, immigrants' rights and employee misclassification .... (and)... for comprehensive immigration reform that supports workplace rights ... and against punitive, anti-immigrant, anti-worker legislation." 23 and also formed a partnership with the IWJ. In 2011, it entered similar agreements with the National Domestic Workers Alliance and the National Alliance of Guestworkers.

The worker centers have grown sufficiently rapidly to generate legal debate over whether they are or not labor organization subject to NLRB laws, which limits their ability to engage in secondary boycotts and necessitates reporting requirements.

The National Domestic Workers Alliance (NDWA) (http://www.domesticworkers.org/) is an NGO that seeks to bring domestic work and the labor conditions of domestic workers to national attention and to establish labor standards for them.It has 42 videos on its YouTube channel telling the story of domestic workers. In 2012 it launched a national campaign focused on the working conditions of people providing direct care to the elderly and people with disabilities. On the legislative front NDWA's main success was in New York, where it got the state to adopt a Domestic Worker's Bill of Rights to ensure basic labor protections for domestic workers. Time Magazine viewed the Alliance as sufficiently promising to name the group's founder, Ai-Jen Poo, one of the 100 most influential people in the world in 2012 - the only person on the list whose occupation was labor activist. ${ }^{24}$

The New York Taxi Workers Alliance (NYTWA) (http://www.nytwa.org/) represents the interests of taxi-drivers in the city much as a traditional trade union would do except that it does not bargain collectively with any employer. AFL-CIO head Richard Trumke gave a YouTube video "thank you" to Bhairavi Desai, founder of the NYC Taxi-drivers alliance ${ }^{25}$ and President Obama recognized Desai and the union for their success at a meeting in DC hosted by the Administration's Office of Faithbased and Neighborhood. ${ }^{26}$ The organization has inspired and assisted the development of similar taxidriver worker alliances in 20 areas of the US and in several foreign countries.

The Freelancers Union (Freelancersunion.org) is a federation of independent workers that advocates for freelancers in the US and that operates a B-corporation Freelancers Insurance company to provide insurance benefits for independent workers in New York State who work in an eligible industry, and meet certain work requirements . By obtaining insurance for large numbers of workers, it is able to charge group health insurance rates and save members considerable money. Initially, the freelancersunion purchased group insurance for its members from commercial insurance companies but since 2008 it has done so through its wholly owned for-profit subsidiary. The organization grew from about 35,000 members in the 1990 s to close to 200,000 members as of January 2013 . With $\$ 340$ million in federal funding it expanded its health plans in New York, New Jersey, and Oregon in 2014. With support from NY it launched a freelancer medical center in Brooklyn in 2013. The freelancersunion does no collective bargaining over wages or working conditions but provides members with information about how to deal with wage arrears, which is a problem for independent workers in almost every field of specialization (Rodgers 2010). It also provides members with online

22 Enriquez (2011)

23 National Day Laborer Organizing Network, 2006

24 See Gloria Steinem (2012)

25 http://www.youtube.com/watch?v=op7IauPe_WI

26 http://www.youtube.com/watch?feature=player_embedded\&v=O7paNg2PP3M\#! 
tools, business management information, networking opportunities, group discount terms with various vendors or partners, and other assistance in working successfully as independents. It sponsored legislation in New York to grant freelancers the same wage protection as traditional employees, to require the Department of Labor to pursue freelancers' unpaid wages, and to hold deadbeat executives liable for up to $\$ 20,000$ and jail time (The Freelancer Payment Protection Act (S4129/A6698)). It receives with considerable grant support from foundations, NYC and New York State. In 2011 Forbes and Businessweek named its founder, Sara Horowitz to their separate lists of Top Social Entrepreneurs.

\section{Employer-based groups}

OUR Walmart (http://forrespect.org/) "The best thing the UFCW can be is a catalyst to help associates build an organization". ${ }^{27}$ In the early 2010s the United Food and Commercial Workers undertook a novel campaign to help the employees/associates at Walmart develop an explicitly nonunion organization from the ground up designed to improve wages and working conditions without collective bargaining. The plan for OUR Walmart was based on research by ASGK public strategy group, which used Facebook to identify Walmart employees and which tested messages that would appeal to them. The organization developed a 12 point declaration that asked Walmart to improve conditions in various ways and to "provide wages and benefits that ensure that no Associate has to rely on government assistance" and to share profits and treat Associates as partners. ${ }^{28}$

OUR Walmart burst to national attention in fall 2012, when members struck for a day at a California warehouse. The organization then promised a one-day protest/strike on the postThanksgiving Black Friday sales day. Though the number of workers who went on strike on Black Friday was miniscule compared to Walmart's 1.4 million US employees, ${ }^{29}$ the strike received national attention. Walmart and some analysts derided the strike as a failure as it did not interfere with the operation of stores nor harm company sales. But OUR Walmart and other analysts viewed the strike as a success. The strike gained the attention of Walmart management, which sought but failed to get an injunction against the strike from the NLRB and felt it necessary to hold anti-union meetings in many stores and to offer workers an extra discount on their Walmart purchases on that day. Some workers joined the organization or went out on strike in response to management pressures. ${ }^{30}$

In 2012 OUR Walmart reported that it had about 4000 members, who pay dues of $\$ 5$ per month, and reported 2,229 signatures to its declaration. If OUR Walmart keeps raising issues and protesting conditions and growing its membership, it has proven that it can force management to respond. Over time, it will induce greater attention to human resource policies and possibly lead the firm to raise wages and benefits to choke off further growth of the organization. Whether OUR Walmart can go beyond that and become an organization that the firm feels compelled to "meet and confer" over employee issues depends not only on its galvanizing workers but also gaining support from the store's customers.

public sector unions in states that ban public sector collective bargaining. Five states Georgia, and North Carolina, South Carolina, Texas, and Virginia, - ban collective bargaining by state

28 The declaration is available at http://forrespect.nationbuilder.com/sign_the_declaration

30 Joel Griffith (2012) gives the case for the protests as failure, while Josh Eidelson (2012a,b,c), who live-blogged the Black Friday strike, gives the case for its success. 
and local public employees; and several other states, such as Mississippi and Arizona make bargaining difficult so that most public sector employees who form unions are unable to obtain contracts. Despite that, a substantial number of state and local workers join unions in those states and in other states where public sector unions do not gain collective bargaining agreements. In three of the five states that ban teachers bargaining -- Texas, Virginia, and Georgia -- a majority of teachers are union members. And the unions in these settings generally obtain better outcomes for their members in the form of pay, benefits, or working conditions. How? The non-collective bargaining unions sign meet and confer agreements with local governments, lobby legislatures on laws regarding employment and budgets and campaign for candidates favorable to their members, much as do some of the private sector noncollective bargaining groups. Their effects appear to be larger the higher their level of density (Freeman and Han, 2012).

In short, in the public sector and in the private, the absence of collective bargaining need not mean the end of unionism nor of the ability of workers to affect the conditions of labor.

\section{Lessons from US experience.}

have experimented with innovative non collective bargaining modes of representing workers interests inside and outside companies. Some of these organizations fit with the "Open Source Union" model (Freeman and Rogers, 2002, 2006) that Joel Rogers and I proposed over a decade ago to engage workers outside of collective bargaining by using modern information communication technology. Some of the new non-collective bargaining organizations have gone beyond what we envisaged, as the expansion of the Internet and development of social media has widened the possible ways for groups to press for changes. Traditional unions have begun to move in the same direction, either to support innovative non-union groups or to learn from them how best to navigate an economic environment where collective bargaining is in abeyance. Compared to the status of emerging labor institutions for the $21^{\text {st }}$ century in 2012 with the review of their situation in the 2000 NBER conference, the "second chapter" in the story of labor organizations and activists seeking to help workers in non-traditional ways holds considerable promise.

Unions and related labor organizations gain members when people are upset at their economic situation and see joining together as a way to improve themselves and the larger economy. The implosion of Wall Street, the ensuing Great Recession and sluggish job recovery have brought the weaknesses of the US economy to the fore and produced widespread dissatisfaction with the US brand of capitalism. It is difficult to imagine the country successfully addressing the issues relating to labor inequality; stagnant real wages for the bulk of the work force; poverty level earnings and benefits for low paid workers, continued high rates of joblessness - without a strong labor movement. But it is also difficult to imagine a union movement wedded to collective bargaining taking the lead in rebuilding a strong labor presence in the economy in a world where collective bargaining is off the map for most workers. At the risk of having some future scholar cite my shortsightedness of where society may be heading, as I have cited Barnett's 1932 prediction, I see reason to believe that the diverse forms of social experimentation described here will give labor a more potent influence on society than it has today.

In the immediate aftermath of the implosion of Wall Street, I thought that the governments of advanced countries would naturally seek to remedy the situation. I expected massive reforms of the financial sector, severe penalties for the illegal and amoral behavior of the banks-too-big-to-fail and the beginning of an effort to shrink the financialization of the economy and to seek ways to develop a more inclusive form of capitalism that would strengthen the economic position of the fabled middle 
class. Some governments and international agencies have sought to rein in the risk-taking excesses of capital markets, but six years after the meltdown of Wall Street, what most impresses me is the resilience and power of finance and moneyed interests to maintain themselves while imposing the costs of the economic disaster onto the rest of society. Finance may have f'd Unless "labor", by which I mean white collar as well as blue collar workers, nonunion as well as unionized workers, rejuvenates itself as an active determinant of change, workers will pay the costs of the wreckage in many countries into the foreseeable future. 
Table 1. Three Types of New Non-collective Bargaining Labor Organizations in the US

\begin{tabular}{|c|c|c|c|}
\hline Institution & Organization & Problem Addressed & Activity \\
\hline \multicolumn{4}{|l|}{ Society Based } \\
\hline Occupy movement & $\begin{array}{l}\text { Diverse, many } \\
\text { college grads }\end{array}$ & $\begin{array}{l}\text { Inequality; finance } \\
\text { issues; varies by } \\
\text { region }\end{array}$ & $\begin{array}{l}\text { Publicity; } \\
\text { demonstrations }\end{array}$ \\
\hline $\begin{array}{l}\text { Internet petition sites } \\
\text { (change.org }{ }^{31} \text {; signon.org, and } \\
\text { others) }\end{array}$ & For profit business & User determined & Publicity via petitions \\
\hline Working America & $\begin{array}{l}\text { AFL-CIO } \\
\text { community affiliate }\end{array}$ & $\begin{array}{l}\text { Local issues; electoral } \\
\text { information; links to } \\
\text { Unionplus benefits }\end{array}$ & Ballot box \\
\hline \multicolumn{4}{|c|}{ Occupation/Industry Based-- Immigrant Centered } \\
\hline $\begin{array}{l}\text { Worker Centers; National } \\
\text { Domestic Workers; NY Taxi- } \\
\text { Workers alliance. }\end{array}$ & $\begin{array}{l}\text { NGO, religious, } \\
\text { foundations, fund } \\
\text { raising; non, CB } \\
\text { union }\end{array}$ & $\begin{array}{l}\text { Workplace issues, } \\
\text { accessing benefits, } \\
\text { immigrant rights; } \\
\text { domestic workers, taxi }\end{array}$ & $\begin{array}{l}\text { Help with } \\
\text { "grievances" expose } \\
\text { bad practices, } \\
\text { advocacy, targeting } \\
\text { employers }\end{array}$ \\
\hline Freelancersunion $^{32}$ & $\begin{array}{l}\text { NGO, foundation } \\
\text { support. Sells low } \\
\text { cost health insurance }\end{array}$ & $\begin{array}{l}\text { Worker health } \\
\text { insurance; wage } \\
\text { arrears problems }\end{array}$ & $\begin{array}{l}\text { Provide health } \\
\text { insurance benefits; } \\
\text { information }\end{array}$ \\
\hline \multicolumn{4}{|l|}{ Employer-based } \\
\hline OUR Walmart ${ }^{33}$ & $\begin{array}{l}\text { NGO, with UFCW } \\
\text { support }\end{array}$ & $\begin{array}{l}\text { Improve pay and } \\
\text { conditions in big } \\
\text { profitable firm where } \\
\text { many workers on } \\
\text { public benefits }\end{array}$ & $\begin{array}{l}\text { Publicity; } \\
\text { demonstrations; }\end{array}$ \\
\hline $\begin{array}{l}\text { Public Sector Unions in Non- } \\
\text { CB states }\end{array}$ & Unions & $\begin{array}{l}\text { Wages, benefits, work } \\
\text { conditions }\end{array}$ & $\begin{array}{l}\text { Politics, lobbying, } \\
\text { meet and confer } \\
\text { agreements }\end{array}$ \\
\hline
\end{tabular}

i In first quarter of 1981 the US had 91.1 million employees. In first quarter of 2001 it 132.5 million employees, based on Total nonfarm employees (PAYEMS) data from FRED, Federal Reserve of St. Louis data base.

ii Relatively more Americans than Europeans worked full-time, and Americans took shorter vacations and holidays than employees in other advanced countries. Since greater work time means less leisure time, some analysts viewed the US advantage in hours worked as a negative feature of the US system.

31 http://www.change.org/ and http://www.change.org/about, accessed December 12, 2012

32 http://www.freelancersunion.org/about/history.html. For Working Today see Hersch (2004)

33 Greenhouse (2011a) 
iii IMF, 2003, chapter 4, p 131

iv These headlines or titles are from Coy, 2008, Kenworthy (2011), Lauffenberg (2011), Lynn and Longman (2010)

v For the German miracle see (Boysen-Hogrefe, Jens and Dominik Groll, 2010; Burda, Michael C., and Jennifer Hunt. 2011; Rinne, Ulf, and Klaus Zimmerman. 2012.

\section{References}

AFL-CIO, NDWA. 2011. "Open Letter from the AFL-CIO and National Domestic Workers Alliance (USA) to Trade Unions and National Centers Around the World." (May 18).

Burnham, Linda and Nik Theodore. 2012. Home Economics: The Invisible and Unregulated World of Domestic Work. New York, NY: National Domestic Workers Allliance.

Colgrass, Neal. 2011. "How a College Grad Helped Sink BoFa's Debit Card Fee." Newser (November 7). Available at: http://www.newser.com/story/132782/how-molly-katchpole-sunk-bank-of-americasdebit-card-fee.html

Combs, Robert. 2012a. "Labor Stats and Facts: Lockout Rates Continue to Surge." Labor and Employment Blog, Bloomberg BNA (October 17). Available at http://www.bna.com/labor-stats-facts$\underline{\text { b17179870280/ }}$

Combs, Robert. 2012b. Labor Stats and Facts: Lockouts Last Longer than Strikes.” Labor and Employment Blog, Bloomberg BNA (November 8). Available at http://www.bna.com/labor-stats-facts$\underline{\text { b17179870766/ }}$

Diamond, Wayne J. and Richard B. Freeman. 2002. "Will Unionism Prosper in Cyberspace? The Promise of the Internet for Employee Organization.” British Journal of Industrial Relations 40(3): 56996.

Dilek, Emine. 2013. “Occupy Movement: What? Who? Why?” (posted January 12). Available at: http://www.progressivepress.net/occupy-movement-what-who-why/

Eidelson, Josh. 2012a. "With Biggest Strike Against Biggest Employer, Walmart Workers Make History Again." The Nation (November 23). Available at:

http://www.thenation.com/blog/171435/biggest-strike-against-biggest-employer-walmart-workersmake-history-again

Eidelson, Josh. 2012b. "Why Walmart Failed to Suppress Black Friday Strikes." Nation in the News (November 26). Available at: http://www.thenation.com/blog/171447/josh-eidelson-walmarts-failingstrike-suppression\#

Eidelson, Josh. 2012c. OUR Walmart Organizers Promise Multi-Pronged December.” The Nation (November 29). Available at: http://www.thenation.com/blog/171528/walmart-organizers-promise-multi-pronged-december

Enriquez, Dianne. 2011. “IWJ Worker Center Network Census.” Workers' Center Network: Interfaith 
Worker Justice. Available at: http://files.www.iwj.org/worker-center-network/labor-law/2011_WCN_Census.pdf

Fine, Janice. 2006. Worker Centers: Organizing Communities at the Edge of the Dream. Ithaca, NY: EPI/Cornell University Press.

Freeman, Richard B. 1998. "Spurts in Union Growth: Defining Moments and Social Processes." In The Defining Moment: The Great Depression and the American Economy in the Twentieth Century, edited by Michael D. Bordo, Claudia Goldin and Eugene N. White. Chicago, IL: University of Chicago Press for NBER.

Freeman, Richard B. and Eunice Han. 2012. "The War Against Public Sector Bargaining in the U.S." Journal of Industrial Relations, Annual Review of Industrial Relations 54(3) (June 2012): 386-407.

Freeman, Richard B. and Marit Rehavi. 2009. "Helping Workers Online and Offline: Innovations in Union and Worker Organization Using the Internet." In Studies of Labor Market Intermediation, edited by David H. Autor. Chicago, IL: University of Chicago Press for NBER: 273 - 306.

Freeman, Richard B. and Joel Rogers. 2002. "Open Source Unionism: Beyond Exclusive Collective Bargaining." WorkingUSA 5(4): 8-40 (March).

Frellick, Marcia. 2012. "Verizon Drops Fees Amid Consumer Protest." CreditCardGuide, Blog. Available at: http://www.creditcardguide.com/credit-cards/verizon-drops-fees-amid-consumerprotest.html\#ixzz1n9xLs3Nn

Godard, John and Carola Frege. 2010. "Union Decline, Alternative Forms of Representation, and Workplace Authority Relations in the United States (November 10). Available at SSRN: http://ssrn.com/abstract=1729768 or http://dx.doi.org/10.2139/ssrn.1729768

Greenhouse, Steven. 2011a. "Wal-Mart Workers Try the Nonunion Route. New York Times (June 14). Print edition, page B1 (June 15). Available at http://www.nytimes.com/2011/06/15/business/15walmart.html?pagewanted=all

Madland, David and Karla Walter. 2010. "Why Is the Public Suddenly Down on Unions?" Center for American Progress Action Fund, American Worker Project, Report (July 2010). Available at: http://www.americanprogressaction.org/wp-content/uploads/issues/2010/07/pdf/union_opinion.pdf

Marculewicz, S., Esquire and Thomas, J., Esquire. 2012. "Labor Organizations by Another Name: The Worker Center Movement and Its Evolution into Coverage Under the NLRA and LMRDA." Engage 13(3): 64-83 (October). Available at: http://www.fedsoc.org/doclib/20121119_WorkerCenterEngage13.pdf

National Day Laborer Organizing Network. 2006. “AFL-CIO \& NDLON Enter Watershed Agreement to Improve Conditions for Working Families." Press Release. Available at: http://www.wcl.american.edu/hrbrief/14/3rathod.pdf 
Rodgers, William M. III. 2010. "The Threat of Nonpayment: Unpaid Wages and New York's SelfEmployed." Report for the Heldrich Center for Workforce Development, Bloustein School of Planning and Public Policy, Rutgers, The State University of New Jersey (June): 1-14. Available at: https://fures.org/pdfs/advocacy/2010-unpaid-wages-report.pdf

Rogers, Simon. 2011. "Occupy Protests Around the World: Full List Visualized. The Guardian DataBlog (November 14). Aavailable at http://www.guardian.co.uk/news/datablog/2011/oct/17/occupyprotests-world-list-map\#data

Saad, Lydia. 2011. "Americans Decry Power of Lobbyists, Corporations, Banks, Feds.” Gallup Politics (April 11). Available at: http://www.gallup.com/poll/147026/americans-decry-power-lobbyistscorporations-banks-feds.aspx

Silver, Nate. 2009. "As Unemployment Rises, Support for Organized Labor Falls.” FiveThirtyEight: Politics Done Right (September 7). Available at: http://www.fivethirtyeight.com/2009/09/asunemployment-rises-support-for.html

Steinem, Gloria. 2012. “Ai-jen Poo: Labor organizer.” Time Lists, The world's 100 most influential people (April 18). Available at:

http://www.time.com/time/specials/packages/article/0,28804,2111975_2111976_2112169,00.html

US Bureau of Labor Statistics Union members summary USDL 13-0105 Available at http://www.bls.gov/news.release/union2.nr0.htm

Wikipedia Contributors. 2012. "Worker Center." (Date of last revision, May 9. Retrieved January 16, 2013). Permanent link: http://en.wikipedia.org/w/index.php?title=Worker_center\&oldid=491527255

Wikipedia Contributors. 2013a. "Change.org" (Date of last revision, January 14. Retrieved January 21). Available at: http://en.wikipedia.org/wiki/Change.org 